\title{
Asymmetric Multicomponent Reactions: Diastereoselective Synthesis of Substituted Pyrrolidines and Prolines
}

\author{
Arun K. Ghosh", Sarang Kulkarni, Chun-Xiao Xu, and Phillip E. Fanwick \\ Departments of Chemistry and Medicinal Chemistry, Purdue University, West Lafayette, IN 47907
}

\begin{abstract}

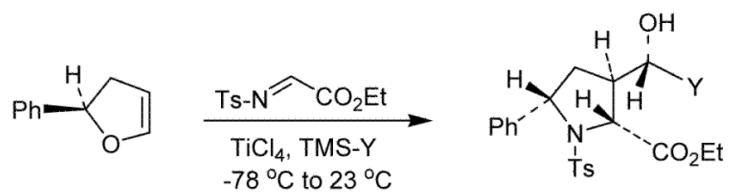

(up to $99: 1$ dr and $83 \%$ yield)

A novel diastereoselective synthesis of substituted pyrrolidines has been developed. Asymmetric multi-component reactions of optically active phenyldihydrofuran, $N$-tosyl imino ester and silane reagents in a one-pot operation afforded highly substituted pyrrolidine derivatives diastereoselectively. The reaction is quite efficient and constructed up to three stereogenic centers in a single operation.
\end{abstract}

\begin{abstract}
Multicomponent reactions (MCRs) that provide functionalized heterocyclic scaffolds in a single operation and in a stereodefined manner are of enormous importance in synthetic organic and medicinal chemistry. Despite the significance and potential of MCRs, there exist only few versatile multicomponent reactions that truly generate diverse molecules with multiple stereocenters. ${ }^{1}$ Our development of multicomponent reactions led to syntheses of a variety of substituted tetrahydrofurans, and tetrahydropyrans containing multiple stereocenters. ${ }^{2}$ Recently, we described multicomponent reactions with $N$-tosyl imino ester that provided rapid access to a range of functionalized novel $\alpha$-amino acids containing cyclic ether templates. ${ }^{3}$ As depicted in Scheme 1, multicomponent reactions of $N$-tosyl imino ester with optically active phenyl dihydrofuran $(\mathbf{1})$ at $-78{ }^{\circ} \mathrm{C}$ to $-20^{\circ} \mathrm{C}$ in the presence of allyltrimethylsilane as the nucleophile and $\mathrm{CH}_{3} \mathrm{CN}$ as the additive provided a single diastereomer $\mathbf{2}$ in very good yield. Interestingly, in the absence of $\mathrm{CH}_{3} \mathrm{CN}$ additive, this multicomponent reaction typically afforded tetrahydrofuran derivative $\mathbf{2}$ along with varying amount (15-30\%) of pyrrolidine derivative 3a as the byproduct. Presumably, a Lewis acidcatalyzed intramolecular rearrangement led to the formation of pyrrolidine derivative $\mathbf{3}$. The presence of $\mathrm{CH}_{3} \mathrm{CN}$ additive completely prevented the formation of pyrrolidine derivative 3 . Pyrrolidine rings are inherent to numerous bioactive natural products and medicinal agents. ${ }^{4}$ The biological significance of functionalized pyrrolidines and prolines continues to stimulate interest in their design and synthesis. In this context, a number of practical synthetic methodologies have been developed recently. ${ }^{5}$ In our continuing interest in probing enzyme active sites with designed ligands containing heterocyclic templates, ${ }^{6}$ we sought to optimize the above multicomponent reaction conditions so as to synthesize functionalized pyrrolidine heterocycles in a stereopredictable manner. Herein we report asymmetric multi-component reactions of optically active phenyldihydrofuran, $N$-tosyl
\end{abstract}

*akghosh@purdue.edu .

Supporting Information Available: Experimental procedures, spectral data for compounds 3-5, and ${ }^{1} \mathrm{H}$ NMR and ${ }^{13} \mathrm{C}$ NMR spectra for compounds 3-5. This material is available free of charge via the Internet at http://pubs.acs.org. 
imino ester and silane reagents in a one-pot operation to afford functionalized pyrrolidine and proline derivatives diastereoselectively.

As mentioned, the above multicomponent reaction of $\mathrm{N}$-tosyl imino ester, ${ }^{7} 5$-phenyl dihydrofuran (1) $\mathbf{1}^{8,9}$ and allyltrimethylsilane in the absence of $\mathrm{CH}_{3} \mathrm{CN}$ additive provided phenyl tetrahydrofuran $\mathbf{2}$ along with pyrrolidine derivative $\mathbf{3 a}$ as the byproduct. We anticipated that the formation of pyrrolidine byproduct $3 \mathbf{a}$ evolved from phenyl tetrahydrofuran 2 by a $\mathrm{TiCl}_{4}$-promoted formation of benzylic carbocation followed by intramolecular ring closure with the sulfonamide. To examine this presumption, phenyltetrahydrofuran 2 was treated with 1.2 equiv of $\mathrm{TiCl}_{4}$ in $\mathrm{CH}_{2} \mathrm{Cl}_{2}$ at $-78{ }^{\circ} \mathrm{C}$ and the resulting mixture was warmed to $23{ }^{\circ} \mathrm{C}$ for $2 \mathrm{~h}$. Indeed, phenyl tetrahydrofuran 2 smoothly converted to pyrrolidine derivative $\mathbf{3 a}$ as a single diastereomer in $90 \%$ yield. We then optimized the multicomponent reaction conditions to provide pyrrolidine derivative $\mathbf{3 a}$. Thus, asymmetric multicomponent reactions leading to effective synthesis of various functionalized pyrrolidines were carried out as follow. Optically active phenyldihydrofuran (1, 1.2 equiv) and $N$-tosyl imino ester (1 equiv) in $\mathrm{CH}_{2} \mathrm{Cl}_{2}$ were treated with $\mathrm{TiCl}_{4}(1 \mathrm{M}$ soln in $\mathrm{CH}_{2} \mathrm{Cl}_{2}, 1.2$ equiv) at $-78{ }^{\circ} \mathrm{C}$ for $1 \mathrm{~h}$. Allyltrimetylsilane ( 3 equiv) was added, and the resulting mixture was allowed to warm to $23^{\circ} \mathrm{C}$ and stirred for $1 \mathrm{~h}$. After this period, the reaction was quenched with saturated aqueous $\mathrm{NaHCO}_{3}$ solution. Standard workup and flash chromatography over silica provided pyrrolidine derivative $\mathbf{3 a}$ in $72 \%$ yield as a single diastereomer (by ${ }^{1} \mathrm{H}$ and ${ }^{13} \mathrm{C}$ NMR analysis). Reduction of $\mathbf{3 a}$ with $\mathrm{NaBH}_{4}$ in the presence of $\mathrm{CaCl}_{2}$ in a mixture of EtOH and THF afforded diol 4 in $88 \%$ yield. The assignment of stereochemistry of the three new chiral centers of 3a was made based upon the X-ray structure of $\mathbf{4}$ in Figure 1 as well as extensive Noesy experiments. ${ }^{10}$ Optical purity of compound $\mathbf{4}$ was determined by its conversion to the corresponding Mosher ester. ${ }^{11}$ The ${ }^{19}$ F-NMR analysis of the Mosher esters established that the optical purity was $87 \%$ ee. Compound 3a was also converted to proline derivative $\mathbf{5}$ by saponification using aqueous $\mathrm{LiOH}$ followed by exposure of the resulting acid to $\mathrm{Na}-\mathrm{Hg}$ in methanol at reflux. ${ }^{12}$ Proline derivative 5 was obtained in $72 \%$ yield in a twostep sequence.

We investigated the feasibility of this reaction protocol with a number of nucleophiles and the results are summarized in Table 1. Multicomponent reactions with allyltributylstannane in the presence of 1.2 equiv of $\mathrm{TiCl}_{4}$ proceeded with excellent diastereoselectivity $(d r=$ 99/1, Table 1, entry 2) and good yield. When triethylsilane was used as a nucleophile pyrrolidine derivatives were obtained as a mixture of diastereomers $(d r=90 / 10$, Table 1 , entry 3). The corresponding reactions with tributyltinhydride also provided pyrrolidine derivative $\mathbf{3 b}$. However, diastereoselectivity and yield were futher reduced (Table 1, entry 4). We then examined a number of enolsilanes and ketene acetals as the nucleophiles. These reactions were considerably sluggish in the presence of 1.2 equiv of $\mathrm{TiCl}_{4}$. Multicomponent reactions with enolsilane $6 \mathbf{a}$ in the presence of 1.2 equiv of $\mathrm{TiCl}_{4}$ at $-78{ }^{\circ} \mathrm{C}$ to $23{ }^{\circ} \mathrm{C}$ provided a mixture $(\sim 1: 1)$ of tetrahydrofuran and pyrrolidine derivatives. The use of 4.2 equiv of $\mathrm{TiCl}_{4}$ however, afforded only pyrrolidine derivative $\mathbf{3 c}$ as a single diastereomer in $63 \%$ yield (Table 1, entry 5). The corresponding reaction with tert-butyl enol ether $\mathbf{6 b}$ also gave a single diastereomer $3 \mathbf{d}$ in excellent yield (Table 1, entry 6). These reactions with ketene acetals $\mathbf{6 c}$ and $\mathbf{6 d}$ also proceeded with excellent diastereoselectivity.

Lewis acid-catalyzed formation of pyrrolidines as well as high degree of diastereoselectivity associated with these reactions can be rationalized based upon the proposed models in Scheme 2. As described previously, ${ }^{3}$ we presume that reaction of phenyl dihydrofuran and $\mathrm{N}$-tosyl imino ester in the presence of $\mathrm{TiCl}_{4}$ at $-78{ }^{\circ} \mathrm{C}$ would furnish oxocarbenium ion 7 which minimizes non-bonding interactions in the transition state. Reaction of 7 with allytrimethylsilane at $-78{ }^{\circ} \mathrm{C}$ to $-20{ }^{\circ} \mathrm{C}$ in the presence of $\mathrm{CH}_{3} \mathrm{CN}$ would provide tetrahydrofuran 2 as described previously. ${ }^{3}$ However in the absence of $\mathrm{CH}_{3} \mathrm{CN}$, Lewis acid 
activation of tetrahydrofuran would result in a new oxonium ion 8 . The $\mathrm{S}_{\mathrm{N}} 2$ nucleophilic attack of sulfonamide nucleophile ( $N T s$ ) to the LA-activated oxonium ion $\mathbf{8}$ may account for the observed complete inversion for 3a and 3c-f (Table 1, entries 1-2. 5-8). Alternatively, oxonium ion 8 may subsequently lead to a benzylic carbonium ion $\mathbf{9}$. Futher rotation of the carbon-carbon bond around the benzylic carbonium ion could provide an alternate carbonium ion 10. An intramolecular $\mathrm{S}_{\mathrm{N}} 1$ attack by the $N$ Ts is likely to proceed through 9 over $\mathbf{1 0}$ to provide $\mathbf{3 b}$ predominantly because of the absence of developing non-bonding interactions between the phenyl ring and the bulky metal alkoxide. The proposed models account for the observed diastereoselectivity with triethylsilane and tributyltinhydride (Table 1 , entries 3 and 4 ) where steric bulk of metal alkoxide is considerably reduced.

In summary, we have developed highly diastereoselective $\mathrm{TiCl}_{4}$-catalyzed multicomponent coupling reactions to provide functionalized pyrrolidines with multiple stereocenters. The overall process is quite efficient and the protocol has constructed up to three contiguous asymmetric centers in a single operation. Further studies are under investigation in our laboratory.

\section{Supplementary Material}

Refer to Web version on PubMed Central for supplementary material.

\section{Acknowledgments}

Financial support by the National Institutes of Health (GM 53386) is gratefully acknowledged.

\section{References}

(1)(a). For recent reviews of multicomponent reactions, see: Ramon DJ, Yus M. Angew. Chem. Int. Ed. 2005; 44:1602.; (b) Strubing D, Neumann H, Hubner S, Klaus S, Beller M. Tetrahedron Lett. 2005; 61:11345.; (c) Nair V, Sreekumar V, Bindu S, Suresh E. Org. Lett. 2005; 7:2297. [PubMed: 15932182]

(2)(a). Ghosh AK, Kawahama R, Wink D. Tetrahedron Lett. 2000; 41:8425.(b) Ghosh AK, Kawahama R. Tetrahedron Lett. 1999; 40:1083.(c) Ghosh AK, Kawahama R. Tetrahedron Lett. 1999; 40:4751.(d) Ghosh AK, Kawahama R. J. Org. Chem. 2000; 65:5433. [PubMed: 10993380]

(3). Ghosh AK, Xu C-X, Kulkarni SS, Wink D. Org. Lett. 2005; 7:7. [PubMed: 15624964]

(4)(a). Trost BM, Pinkerton AB, Kremzow D. J. Am. Chem. Soc. 2000; 122:12007.(b) Leclercq, S.; Braekman, JC.; Daloze, D.; Pasteels, JM. Progress in the Chemistry of Organic Natural Products. Herz, W.; Falk, H.; Kirby, GW.; Moore, RE., editors. Vol. 79. Springer-Verlag; New York: 2000. p. 115(c) DeGoey DA, Chen H-J, Flosi WJ, Grampovnik DJ, Yeung CM, Klein LL, Kempf DJ. J. Org. Chem. 2002; 67:5445. [PubMed: 12153241] (d) Hanessian S, Bayrakdariyan M, Luo X. J. Am. Chem. Soc. 2002; 124:4716. [PubMed: 11971721]

(5)(a). For recent syntheses of pyrrolidines: David FA, Xu H, Wu Y, Zhang J. Org. Lett. 2006; 8:2273. [PubMed: 16706504] (b) Cabrera S, Arrayas RG, Carretero JC. J. Am. Chem. Soc. 2005; 127:16394. [PubMed: 16305216] (c) Hanessian S, Yun H, Hou Y, Tintelnot-Blomely M. J. Org. Chem. 2005; 70:6746. [PubMed: 16095294] (d) Liu Z, Rainier JD. Org. Lett. 2005; 7:131. [PubMed: 15624995] (e) Garner P, Kaniskan HU. J. Org. Chem. 2005; 70:10868. [PubMed: 16356011] (f) Kumareswaran R, Shin S, Gallou I, RajanBabu TV. J. Org. Chem. 2004; 69:7157. [PubMed: 15471465]

(6). Ghosh AK, Kincaid JF, Cho W, Walters DE, Krishnan K, Hussain KA, Cho H, Rudall C, Holland L, Buthod J. Bioorg. Med. Chem. Lett. 1998; 8:687. [PubMed: 9871583]

(7)(a). Tschaen DM, Turos E, Weinreb SM. J. Org. Chem. 1984; 49:5058.(b) Weinreb SM. Top. Curr. Chem. 1997; 190:131. 
(8)(a). Phenyl dihydrofuran was prepared using asymmetric Heck reactions in optically enriched form, see: Ozawa F, Kubo A, Hayashi T. Tetrahedron Lett. 1992; 33:1485.; (b) Ozawa F, Kubo A, Hayashi T. J. Am. Chem. Soc. 1991; 113:1417.

(9). Optical purity of 5-phenyl dihydrofuran was $88 \%$ ee.

(10). Crystal data for $4: \mathrm{C}_{22} \mathrm{H}_{27} \mathrm{NO}_{4} \mathrm{~S}$; $\mathrm{MW}=401.53$; colorless crystal; crystal system, block; space group, P 21; cell parameters, $a=13.99719(11) \AA, b=10.4573(4) \AA, c=14.4138(11) \AA$, $\beta$ $=96.230(3)^{\circ}, V=2097.3(2) \AA^{3}, Z=4$; Mo K $\alpha$ radiation $(\lambda=0.71073 \AA, \mathrm{T}=150 \mathrm{~K}), R 1=0.045$, $\mathrm{w} R 2=0.076(I>2 \sigma(I)) ; \mathrm{R}_{1}=0.081, \mathrm{wR}_{2}=0.089$ (all data). Crystallographic data has been deposited with the Cambridge Crystallographic Data Center (deposition no. 611303). This data can be obtained free of charge via the Internet at www.ccdc.cam.ac.uk/data_request/cif, by email to data_request@ccdc.cam.ac.uk, or by contacting The Cambridge Crystallographic Data Centre, 12, Union Road, Cambridge CB2 1EZ, UK.

(11). Dale JA, Dull DL, Mosher HS. J. Org. Chem. 1969; 34:2543.

(12)(a). Birkinshaw TN, Holmes AB. Tetrahedron Lett. 1987; 28:813.(b) Chavez F, Sherry AD. J.Org. Chem. 1989; 54:2990. 


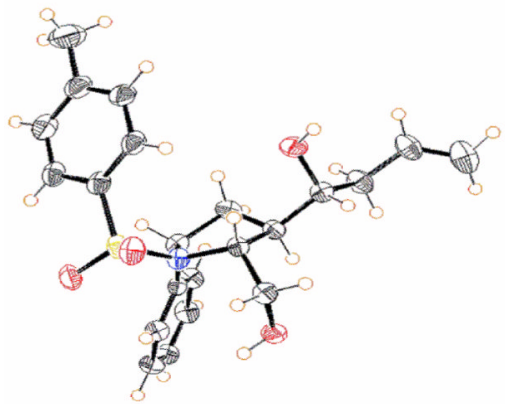

Figure 1.

ORTEP drawing of X-ray structure of $\mathbf{4}$ 

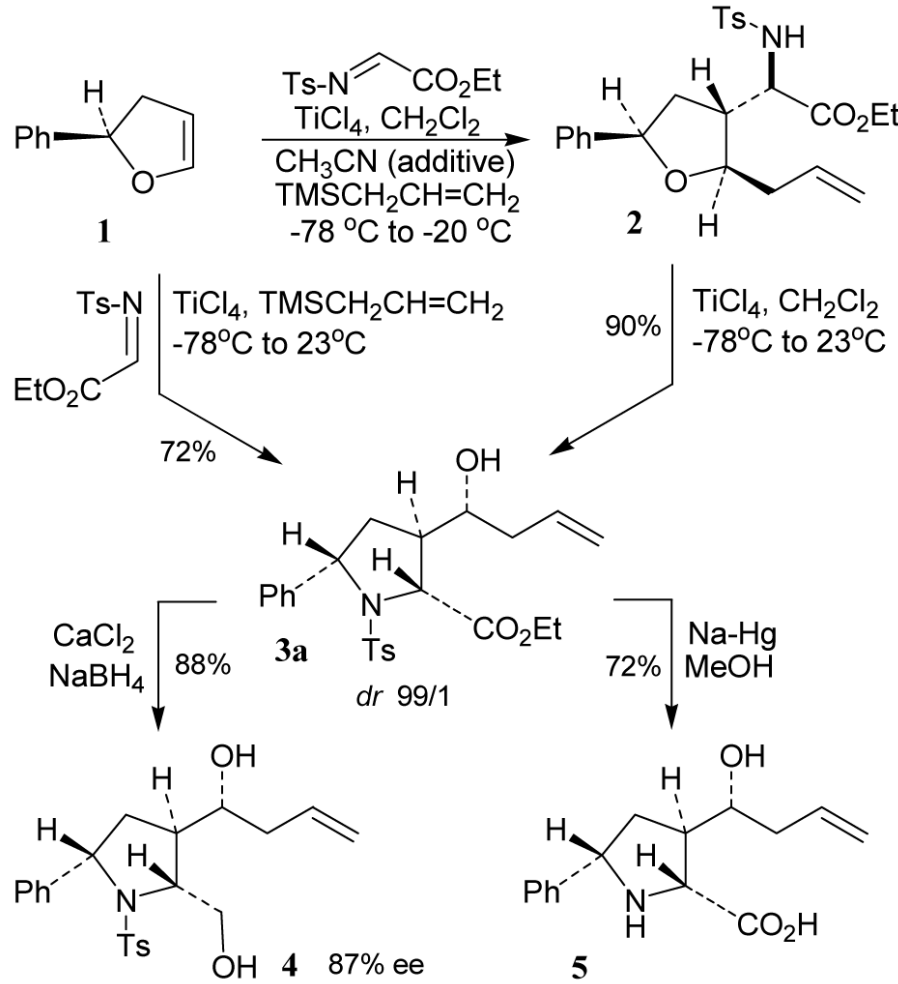

Scheme 1.

Asymmetric multicomponent reaction 


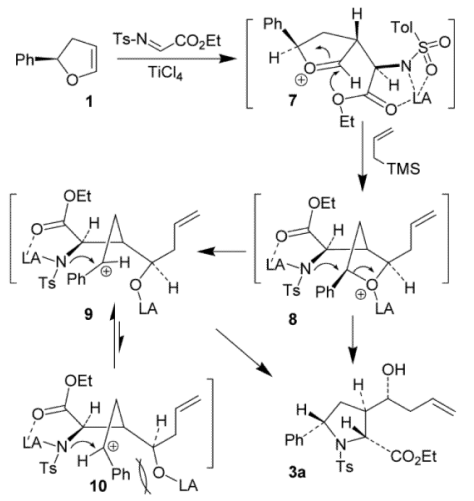

Scheme 2.

Stereochemical models 


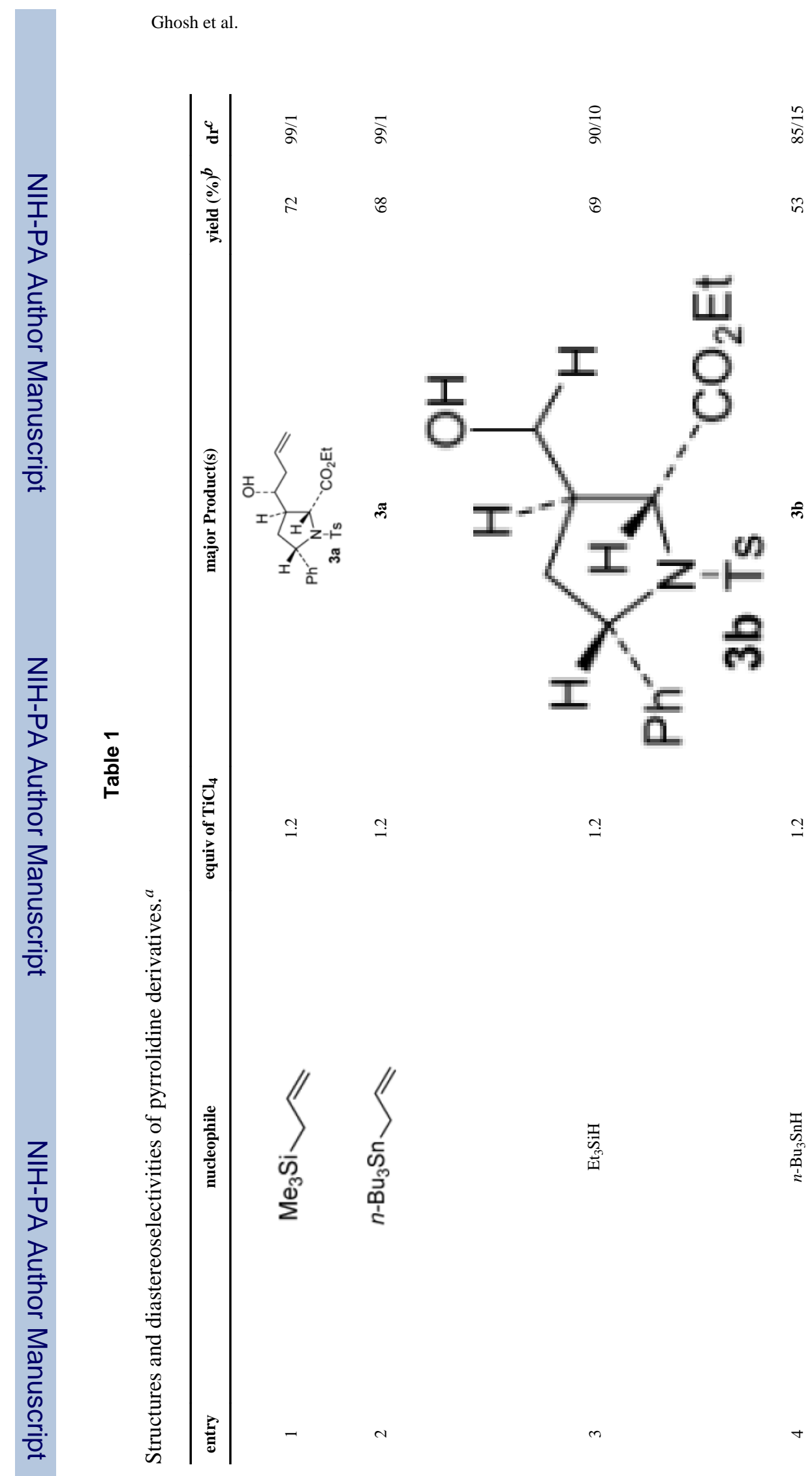

Org Lett. Author manuscript; available in PMC 2011 September 25. 


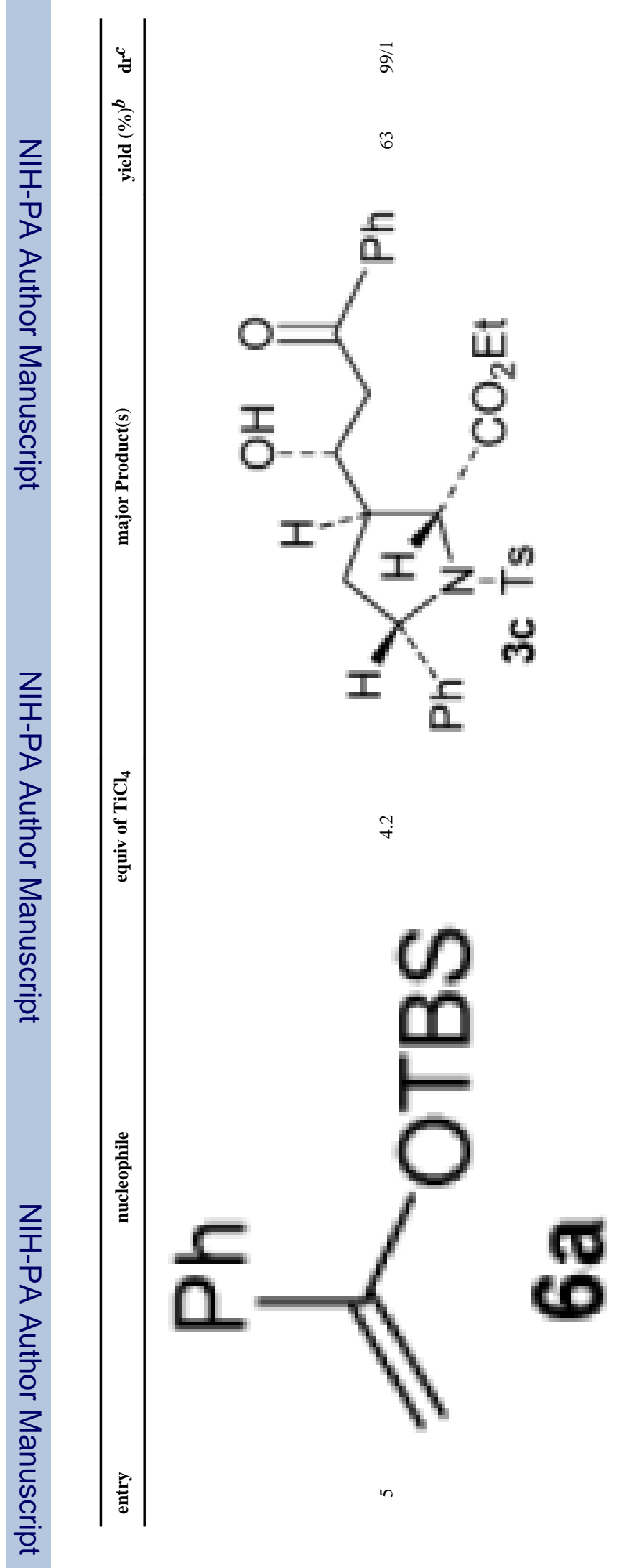

Org Lett. Author manuscript; available in PMC 2011 September 25. 

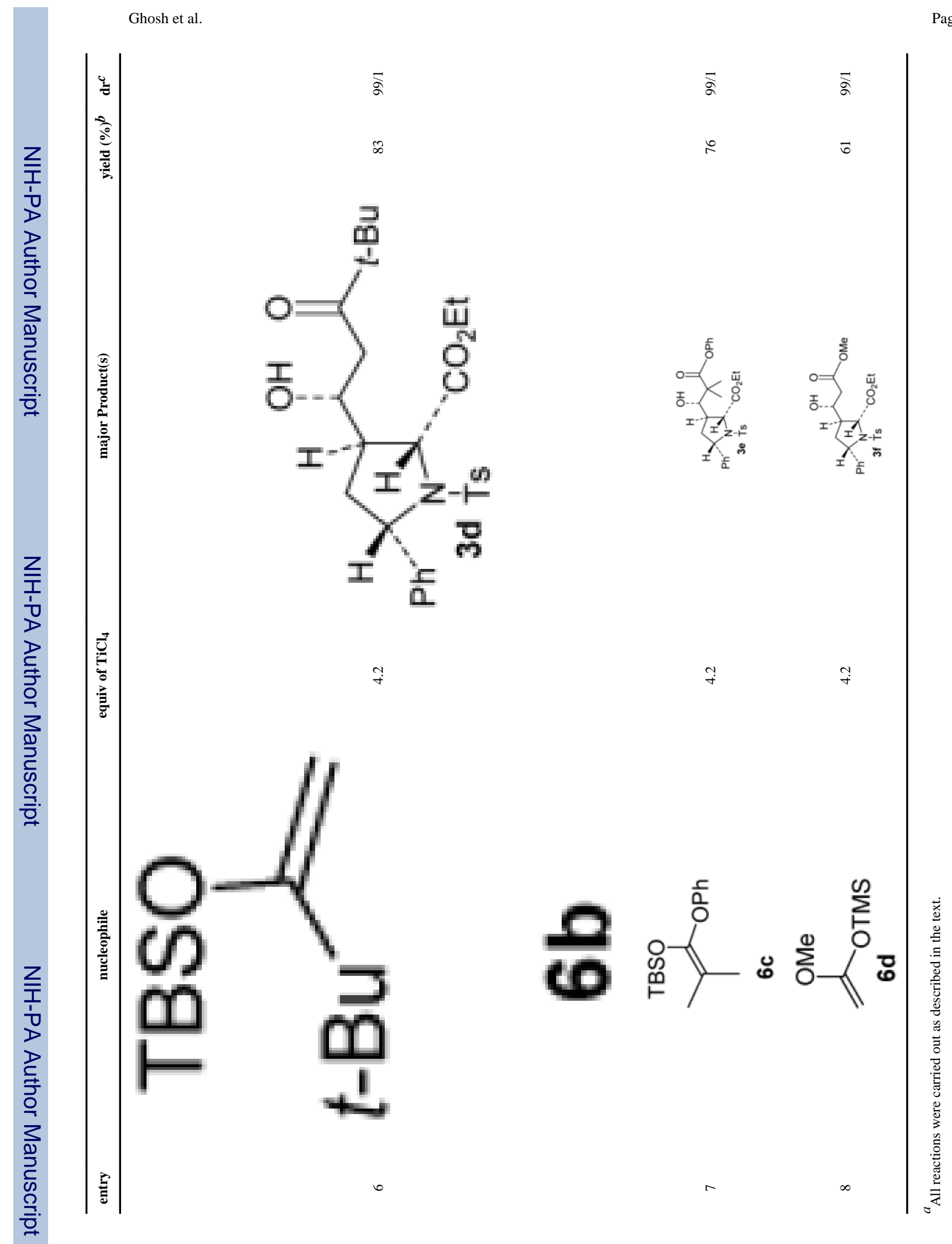

Org Lett. Author manuscript; available in PMC 2011 September 25. 
